Acta Agroph., 2019, 26(1), 25-36

doi: $10.31545 /$ aagr/106221

\title{
IMPACT OF GROWTH BIOSTIMULATORS AND HERBICIDE ON THE YIELD STRUCTURE OF EDIBLE POTATO TUBERS (SOLANUM TUBEROSUM L.)
}

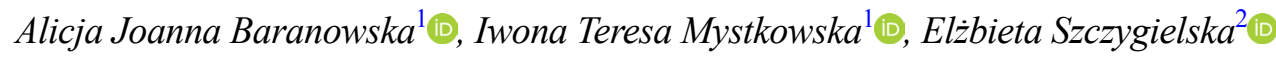 \\ ${ }^{1}$ Department of Agriculture, Pope John II State School of Higher Education in Biala Podlaska \\ ${ }^{2}$ Department of Civil Engineering, Pope John II State School of Higher Education in Biała Podlaska \\ Sidorska 95/98, 21-500 Biała Podlaska, Poland \\ e-mail: alabar@tlen.pl
}

Abstract. The aim of the research was to define the influence of treatment methods, with the use of growth biostimulators and herbicide on the yield structure of three varieties of edible potato. The series of field research was carried out in the years 2015-2017, in the region of eastern Poland, in Biała Podlaska municipality, in Lubelskie voivodship, on light, acidic soil. The experiment was constructed with the use of random sub-blocks method in three repetitions. The tested factors included: I. factor - three early edible potato varieties Owacja, Bellarosa, Vineta; II. factor - five methods of treatment of the field of potato crops with the use of growth biostimulators: GreenOk-Uniwersal Pro and Asahi SL and their combinations with Avatar 293 ZC herbicide. As a result of the conducted research it was found that the methods of treatment with the use of growth biostimulators and herbicide had a positive effect on the structure of potato tuber yields, compared to the standard object on which only mechanical care was applied. The highest weight percent of large tubers input (in fractions $>51 \mathrm{~mm}$ ) was observed in case of experimental object 4. (in case of which herbicide Avatar $293 \mathrm{ZC}$ and GreenOK Universal-PRO preparation were applied) as well as experimental object 3 (post applying biostimulator Asahi SL). Varieties cultivated in the experiment had a significant impact also on the structure of potato crops. An impact of weather conditions on the structure of potato tubers was further noted. Based on the conducted experiment, it can be concluded that the growth biostimulators, as well as their combination with herbicide, positively influenced the quality parameters of potato tubers. Therefore, these preparations should find wider application in agricultural practice.

Key w ords: potato, harvest structure, GreenOK Universal-PRO, Asahi SL, Avatar 293 ZC

\section{INTRODUCTION}

Potato (Solanum tuberosum L.) is an important agricultural plant, not only on account of its consumable value but also its industrial and fodder values. It occupies a significant place in shifting cultivation (Zarzecka et al. 2017). Nowadays, the 
production of potato continues to increase worldwide. The world production of this plant amounted to 376.8 million tonnes in 2016, while in 2017 this number increased to 388.2 million tonnes. Poland remains on the eighth place in the world and on the fourth place in Europe in terms of potato production (9.2 million tonnes). The world potato industry is undergoing substantial changes. Until the early 90 s major part of potatoes was grown and consumed in Europe, North America and former Soviet Union. In the ' 90 s of the last century the world faced an increase in the production and demand for potatoes among the developing countries of: Asia, Africa and Latin America. Currently, one-third of all potatoes are harvested in China and India (FAOSTAT 2019).

In Poland, despite a decreasing cultivation acreage, potato consumption is still high and it totals at about $100 \mathrm{~kg} /$ person/year. However, there is a tendency of constant decrease of fresh potatoes consumption, while the consumption of processed potatoes continues to increase (Potato Market 2015, Report of the Bank of Food Industry and Agriculture Bank 2015).

The basic parameter of quality of tubers in potato production is their appropriate size. The share in the harvest of tubers of various sizes is determined by the harvest structure. The size of potato tubers is one of many indicators of the usable value of varieties, depending on the direction of production. Edible tubers ought to have a diameter exceeding $35 \mathrm{~mm}$, while tubers intended for chips - exceeding $55 \mathrm{~mm}$, and for potato crisps between 40 and $70 \mathrm{~mm}$ (Regulation 2003, Chotkowski and Pilecki 2005, Zarzyńska 2012).

Plenty of factors have an influence on the potato crop size and its structure, among others, genetic traits of varieties, environmental and agronomic factors. (Krzysztofik et al. 2009, Essah et al. 2012, Radzka et al. 2015, Rymuza et al. 2015).

Currently, global trends in plant production are aimed at transforming intensive cultivation of crops into cultivation systems with a reduced share of synthetic fertilizers and chemical means of production for the protection of human and animal life and health as well as for environment protection purposes. New fertilizers and modern fertilization techniques will become increasingly applied in order to improve the quality of crops for the sake of environmental protection in the potato cultivation. On the other hand, chemical plant protection products will be increasingly used on the basis of monitoring threats related to pathogens (Jabłoński 2009, 2012). A very important element of the changes taking place in potato agro-technics is the commonly created process of the so-called "Green marketing of agricultural production space" (Nowacki 2005).

Due to the above, various types of ecological preparations, named biostimulators, are more and more often introduced into agricultural practice (Calvo et al. 2014). These preparations do not have a fertilizing effect, they mostly function on the basis of stimulating physiological processes in plants, increasing the effectiveness of using nutrients and increasing the resistance of plants to stressful 
conditions (Kunicki et al. 2010, Bulgari et al. 2015, Matyaszczyk 2015).They may also positively influence some of the physicochemical features of soil and support the development of beneficial soil microorganisms (Vernieri et al. 2002). Their chemical composition includes many components with stimulating properties, such as: humus substances, effective microorganisms, phytohormones, enzymes, seaweed and fruit extracts, chitin, chitosan, poly-oligosaccharides, chemical elements, inorganic salts, phenolic compounds and many other substances with biologically active properties (Kauffman et al. 2007, Khan et al. 2009, Du Jardin 2012, 2015).

Scarce and ambiguous empirical findings about the influence of growth biostimulators on quality traits of potato tubers encourage further examinations. The aim of the experiment was to observe the impact of five methods of treatment using growth biostimulators and herbicide on the structure of potato tubers. The research hypothesis assumed that treatment methods with the use of growth biostimulators and herbicide would have a positive effect on the potato tuber yield structure through an increased share of large tubers in a yield.

\section{MATERIALS AND METHODS}

\section{Experiment and plant material}

The field research was carried out in the years 2015-2017, in the region of eastern Poland, in Biała Podlaska municipality $\left(52^{\circ} 02^{\prime} \mathrm{N} 23^{\circ} 07^{\prime} \mathrm{E}\right)$, in Lubelskie voivodship, on light, acidic soil classified as quality class IVa. Soil was characterised by very high content of easy absorbed phosphorus and potassium forms. On the other hand, the amount of absorbed magnesium in soil was from average to very high.

The impact of two factors was tested in the experiment:

I. Factor - varieties of edible potato: Bellarosa, Owacja, Vineta;

II. Factor - five methods of treatment of potato field with the use of growth and herbicide biostimulators (Tab. 1).

Each year of carrying out the experiment, in autumn, fertilizing with natural manure was used at a dose of $25 \mathrm{tha}^{-1}$ as well as mineral - phosphorous at a dose of $44.0 \mathrm{~kg} \mathrm{P} \mathrm{ha}^{-1}$ (triple superphosphate $46 \%$ ) and potassium $124.5 \mathrm{~kg} \mathrm{~K} \mathrm{ha}^{-1}$ (potassium salt $60 \%$ ). In contrast, in spring, nitrogen fertilization (ammonium nitrate $34 \%$ ) at a dose of $100 \mathrm{~kg} \mathrm{~N}$ per 1 ha was applied. Potato tubers were planted in the second decade of April (in 2015 and 2016) and in the third decade of April (in 2017). Treatments against diseases and pests were used in accordance with the plant protection recommendations and carried out on cloudy days in the afternoon hours. A battery sprayer equipped with a standard flat-jet nozzle (015-80, in accordance with the ISO standard) was applied to carry out chemical treatments. Potato plantation was protected with insecticides: Actara $25 \mathrm{WG}$ (thiamethoxam $250 \mathrm{~g} \mathrm{~kg}^{-1}$ ) at 
a dose of $0.08 \mathrm{~kg} \mathrm{ha}^{-1}$, Calypso $480 \mathrm{SC}$ (thiachloprid $480 \mathrm{~g} \mathrm{dm}^{3}$ ) at a dose of 0.1 $\mathrm{dm}^{3} \mathrm{ha}^{-1}$ and fungicides: Copper Max New $50 \mathrm{WP}$ (copper $-500 \mathrm{~g} \mathrm{~kg}^{-1}$ ) at a dose of $2.0 \mathrm{~kg} \mathrm{ha}^{-1}$ Dithane Neo Tec $75 \mathrm{WG}$ (mancozeb $750 \mathrm{~g} \mathrm{~kg}^{-1}$ ) at a dose of $2.0 \mathrm{~kg} \mathrm{ha}^{-1}$.

Table 1. Methodical data of the experiment

Treatment methods

1. Standard object - mechanical treatment (without biostimulators and herbicide)

2. From sprouting of potato plants - mechanical treatment and after sprouting $-* \mathrm{GreenOK}$ Universal-PRO bioactivator, three times to leaves: at a dose of $0.10 \mathrm{dm}^{3} \mathrm{ha}^{-1}$ (phase BBCH 13-19) $+0.15 \mathrm{dm}^{3} \mathrm{ha}^{-1}$ (phase BBCH 31-35) $+0.15 \mathrm{dm}^{3} \mathrm{ha}^{-1}$ (phase BBCH 51-55).

3. From sprouting of potato plants - mechanical treatment, and after sprouting $-* *$ Asahi SL bioactivator, three times to leaves at a dose of $0.50 \mathrm{dm}^{3} \mathrm{ha}^{-1}$ (phase BBCH 13-19) $+0.50 \mathrm{dm}^{3} \mathrm{ha}^{-1}$ (phase BBCH 31-35) + 0.50 $\mathrm{dm}^{3} \mathrm{ha}^{-1}$ (phase BBCH 51-55).

4. From sprouting - mechanical treatment, and after the final shaping of ridges and just before sprouting ***Avatar $293 \mathrm{ZC}$ herbicide at a dose of $1.5 \mathrm{dm}^{3} \mathrm{ha}^{-1}$ (phase BBCH 00-05). After sprouting - three applications of GreenOK Universal-PRO bioactivator at a dose of $0.10 \mathrm{dm}^{3} \mathrm{ha}^{-1}$ (phase BBCH 13-19) $+0.15 \mathrm{dm}^{3} \mathrm{ha}^{-1}$ (phase BBCH 31-35) $+0.15 \mathrm{dm}^{3} \mathrm{ha}^{-1}$ (phase BBCH 51-55).

5. From sprouting - mechanical treatment, and after the final shaping of ridges before sprouting of potato plants - Avatar $293 \mathrm{ZC}$ herbicide at a dose of $1.5 \mathrm{dm}^{3} \mathrm{ha}^{-1}$ (phase BBCH 00-05).

*GreenOK Universal-PRO bioactivator (humus substances $\geq 20 \mathrm{~g} \mathrm{dm}^{3}$, and NPK 0.13-0.09-0.7); **Asahi SL bioactivator (sodium para-nitrophenolate $(0.3 \%)$, sodium orto-nitrophenolate $(0.2 \%)$, sodium-nitroguaiacolate (0.1\%); ***Avatar 293 ZC herbicide (clomazone (5.13\%), metribuzin (20.64\%)

The harvest was performed in the phase of full technological ripeness of potato tubers. The area of harvest fields totalled $20 \mathrm{~m}^{2}$. During the harvest, randomly chosen samples of 10 potato plants (with the exception of marginal plants) were collected from each experimental object. In these samples, the structure of harvest was determined according to the fractions with transverse diameter: up to $35,36-$ 50, 51-60 and above $60 \mathrm{~mm}$. The total potato harvest was calculated on the basis of the mass of tubers collected from the surface of each plot of land, adding the mass of previously collected samples. The harvest of fractions with a diameter above $51 \mathrm{~mm}$ was classified to the harvest of large tubers. The results of research concerning total yield have been presented in the work of Baranowska (2018). The results of research on the impact of treatment methods on the harvest structure of potato tubers are based on average percentage values.

\section{Statistical analysis}

A study was carried out on the impact of care and cultivation methods, varieties and weather conditions on the structure of edible potato tuber yield.The obtained research results were elaborated statistically with the use of analysis of variations. The significance of changeability sources was researched by means of $F$ FisherSnedecor test and the assessment of significance of differences at the significance level $p=0.05$ between the averages compared using the multiple Tukey intervals. 


\section{Weather conditions}

The precipitation and thermal conditions during the growing season of potato have been shown in Table 2. The data come from the Meteorological Station of the Polish Official Variety Testing Centre (COBORU) in Stupia Wielka and they were elaborated for the Experimental Station for the Evaluation of Varieties in Cicibór Duży, located near Biała Podlaska. Atmospheric conditions were characterized in the course of several consecutive years (1990-2010) on the basis of average monthly air temperatures $\left({ }^{\circ} \mathrm{C}\right)$, monthly precipitation sums $(\mathrm{mm})$, and Sielianinov's thermal coefficient $(K)$. Extremely dry and extremely humid conditions were distinguished, dividing the values of the Sielianinov's $(K)$ coefficient into nine classes according to Skower (2014).

Table 2. Meteorological conditions in potato's growing season (mean for years 2015-2017)

\begin{tabular}{|c|c|c|c|c|c|c|}
\hline $\begin{array}{l}\text { Month / } \\
\text { Year }\end{array}$ & $\begin{array}{c}\text { Air } \\
\text { temperature } \\
\left({ }^{\circ} \mathrm{C}\right) \\
(\text { monthly } \\
\text { mean) }\end{array}$ & $\begin{array}{c}\text { Air } \\
\text { temperature } \\
\left({ }^{\circ} \mathrm{C}\right) \\
\text { (many years' } \\
\text { mean } \\
1990-2010 \text { ) }\end{array}$ & $\begin{array}{l}\text { Precipitation } \\
\text { sum } \\
(\mathrm{mm})\end{array}$ & $\begin{array}{l}\text { Precipitation } \\
\text { sum (mm) } \\
\text { (many years' } \\
\text { mean } \\
\text { 1990-2010) }\end{array}$ & $\begin{array}{l}\text { Sielianinov } \\
\text { hydrothermal } \\
\text { coefficient } \\
\text { (K) }\end{array}$ & $\begin{array}{l}{ }^{*} \text { Month's } \\
\text { classification } \\
\text { according to } \\
\text { Skowera } \\
(2014)\end{array}$ \\
\hline & & & 2015 & & & \\
\hline IV & 8.3 & 8.3 & 36 & 38 & 1.43 & optimal \\
\hline $\mathrm{V}$ & 12.8 & 13.9 & 91 & 61 & 2.28 & humid \\
\hline VI & 16.7 & 17.0 & 30 & 60 & 0.59 & very dry \\
\hline VII & 19.6 & 19.4 & 49 & 77 & 0.80 & dry \\
\hline VIII & 21.6 & 18.3 & 7 & 68 & 0.11 & extremely dry \\
\hline IX & 15.1 & 12.7 & 75 & 57 & 1.66 & quite humid \\
\hline Mean / Sum & 15.7 & 14.9 & $\begin{array}{l}288 \\
2016\end{array}$ & 361 & 0.99 & \\
\hline IV & 9.7 & 8.3 & 35 & 38 & 1.19 & quite dry \\
\hline V & 15.0 & 13.9 & 22 & 61 & 0.47 & very dry \\
\hline VI & 18.4 & 17.0 & 84 & 60 & 1.53 & optimal \\
\hline VII & 19.8 & 19.4 & 121 & 77 & 1.97 & quite humid \\
\hline VIII & 18.7 & 18.3 & 28 & 68 & 0.48 & very dry \\
\hline IX & 15.2 & 12.7 & 12 & 57 & 0.26 & extremely dry \\
\hline Mean / Sum & 16.1 & 14.9 & $\begin{array}{l}302 \\
2017\end{array}$ & 361 & 1.0 & \\
\hline IV & 7.7 & 8.3 & 62 & 38 & 2.68 & very humid \\
\hline V & 13.8 & 13.9 & 40 & 61 & 0.93 & \\
\hline VI & 18.0 & 17.0 & 106 & 60 & 1.97 & quite humid \\
\hline VII & 18.5 & 19.4 & 71 & 77 & 1.24 & quite dry \\
\hline VIII & 19.9 & 18.3 & 41 & 68 & 0.66 & very dry \\
\hline IX & 14.7 & 12.7 & 105 & 57 & 2.37 & extremely humid \\
\hline Mean / Sum & 15.4 & 14.9 & 425 & 361 & 1.50 & \\
\hline
\end{tabular}

*Month's classification according to Skowera (2014): extremely dry $K \leq 0.4$, very dry $0.4<K \leq 0.7$, dry $0.7<K \leq 1.0$, quite dry $1.0<K \leq 1.3$, optimal $1.3<K \leq 1.6$, quite humid $1.6<K \leq 2.0$, humid $2.0<K \leq 2.5$, very humid $2.5<K \leq 3.0$, extremely humid $K>3.0$ 
Varied meteorological conditions were in place during the research (Tab. 2). In the growing season of 2015 there was a high precipitation deficit in the period from June to August, and the month of August was extremely dry with a total rainfall of 7 $\mathrm{mm}$ and high temperatures of atmospheric air. The Sielianinov's (K) hydrothermal coefficient this month was at the level of 0.11 . In contrast, the most humid season compared to the remaining years of the study was the 2017 vegetation season in which the total rainfall amounted to $425 \mathrm{~mm}$ and it was higher than the average sum from the long-term period by $64 \mathrm{~mm}$. The thermal and rainfall conditions were more favourable as compared to the remaining years of research in the growing season of 2016. The most humid months included: July with total rainfall of $121 \mathrm{~mm}$ and high air temperatures (average $19.8^{\circ} \mathrm{C}$ ) and June with total precipitation of $84 \mathrm{~mm}$ and average air temperature of $18.4^{\circ} \mathrm{C}$ (Tab. 2).

\section{RESULTS AND DISCUSSION}

\section{The impact of methods of treatment on the structure of potato tubers}

When analysing the results of own research it was noted that the methods of treatment with the use of growth biostimulators and herbicide had a positive impact on the structure of potato tubers crop. Based on the conducted statistical calculations, it was noted that the weighted, percentage share of the tubers in the general crop in fractions below 35 and 36-50 mm (Tabs 3 and 4) was indeed higher in case of experimental object 1 , on which only mechanical treatment was applied (without

Table 3. The impact of methods of treatment on the weighted and percentage share of potato tubers in fractions $<35 \mathrm{~mm}$ (on average for cultivars and years 2015-2017)

\begin{tabular}{lllrrrrr}
\hline \multirow{2}{*}{ Methods* } & \multicolumn{5}{c}{ Cultivars } & \multicolumn{3}{c}{ Years } & Mean \\
\cline { 2 - 7 } & Bellarosa & Owacja & Vineta & 2015 & 2016 & 2017 & \\
\hline $1^{*}$ & 8.60 & 8.13 & 14.08 & 11.29 & 8.07 & 11.45 & 10.27 \\
3 & 6.15 & 5.45 & 8.97 & 9.37 & 4.21 & 6.99 & 6.86 \\
4 & 4.00 & 5.04 & 6.50 & 6.17 & 4.50 & 4.87 & 5.18 \\
5 & 2.01 & 4.00 & 5.10 & 4.18 & 3.47 & 3.47 & 3.71 \\
Mean & 3.01 & 6.04 & 7.33 & 5.52 & 5.31 & 5.55 & 5.46 \\
LSD (0.05) for: Years & 4.75 & 5.73 & 8.40 & 7.31 & 5.11 & 6.47 & 6.30 \\
& Cultivars & & & & & & n.s. \\
& Methods & & & & & 1.060 \\
& Years $\times$ methods & & & & & 1.116 \\
& Cultivars $\times$ methods & & & & & n.s. \\
& & & & & & & n.s. \\
\hline
\end{tabular}

* - as in the research methodology: 1. Standard; 2. object (without biostimulators and herbicide); 3. GreenOK Universal-PRO $0.10 \mathrm{dm}^{3} \mathrm{ha}^{-1}+0.15 \mathrm{dm}^{3} \mathrm{ha}^{-1}+0.15 \mathrm{dm}^{3} \mathrm{ha}^{-1}$; 4. Asahi SL $0.50 \mathrm{dm}^{3} \mathrm{ha}^{-1}+0.50 \mathrm{dm}^{3} \mathrm{ha}^{-1}$ $+0.50 \mathrm{dm}^{3} \mathrm{ha}^{-1}$; 5. Avatar $293 \mathrm{ZC} 1.5 \mathrm{dm}^{3} \mathrm{ha}^{-1}+$ GreenOK Universal-PRO $0.10 \mathrm{dm}^{3} \mathrm{ha}^{-1}+0.15 . \mathrm{dm}^{3} \mathrm{ha}^{-1}$ $+0.15 \mathrm{dm}^{3} \mathrm{ha}^{-1} ; 6$. Avatar $293 \mathrm{ZC} 1.5 \mathrm{dm}^{3} \mathrm{ha}^{-1} ; \mathrm{n}$. s. - not significant difference 
growth biostimulators and herbicide) - for small tubers in fractions below $35 \mathrm{~mm}$ it was on average $10.27 \%$ and in fractions $36-50 \mathrm{~mm}-33.6 \%$. The smallest percentage of small tubers in general crop (in fractions: $<35 \mathrm{~mm}$ and $36-50 \mathrm{~mm}$ ) was found in case of experimental object 4 (on average 3.71 and 14.74\%) (Tabs 3 and 4), on which mechanical treatment methods were applied and shortly before emergences of potato plants, on the wet soil the plants were treated with a herbicide called Avatar $293 \mathrm{ZC}$ at a dose of $1.5 \mathrm{dm}^{3} \mathrm{ha}^{-1}$. Then, during the plants' growing period a humus bioactivator GreenOK Universal-PRO was applied three times at a combined dose of $0.40 \mathrm{dm}^{3} \mathrm{ha}^{-1}$, as well as on experimental object 3 (on average 5.18 and $23.04 \%$ ), on which mechanical treatment methods were used until the emergence of potato plants followed by the application of a biostimulator Asahi SL at a combined dose of $1.5 \mathrm{dm}^{3} \mathrm{ha}^{-1}$ (Tabs 3 and 4).

Table 4. The impact of methods of treatment on the weighted and percentage share of edible potato tubers in fractions 36-50 mm (on average for cultivars and years 2015-2017)

\begin{tabular}{|c|c|c|c|c|c|c|c|}
\hline \multirow{2}{*}{ Methods* } & \multicolumn{3}{|c|}{ Cultivars } & \multicolumn{3}{|c|}{ Years } & \multirow{2}{*}{ Mean } \\
\hline & Bellarosa & Owacja & Vineta & 2015 & 2016 & 2017 & \\
\hline $1^{*}$ & 17.07 & 40.87 & 42.25 & 39.04 & 25.60 & 35.55 & 33.40 \\
\hline 2 & 14.85 & 36.22 & 40.36 & 38.96 & 23.46 & 29.01 & 30.48 \\
\hline 3 & 4.67 & 26.96 & 37.50 & 25.50 & 20.83 & 22.80 & 23.04 \\
\hline 4 & 4.99 & 15.33 & 23.90 & 20.82 & 10.53 & 12.87 & 14.74 \\
\hline 5 & 10.99 & 28.29 & 39.67 & 34.81 & 22.69 & 21.45 & 26.32 \\
\hline Mean & 10.51 & 29.53 & 36.74 & 31.83 & 20.62 & 24.34 & 25.60 \\
\hline \multirow[t]{5}{*}{$\operatorname{LSD}(0.05)$ for: } & Years & & & & & & 1.991 \\
\hline & Cultivars & & & & & & 1.991 \\
\hline & Methods & & & & & & 1.956 \\
\hline & Years $\times$ methc & & & & & & n.s. \\
\hline & Cultivar $\times$ me & & & & & & n.s. \\
\hline
\end{tabular}

* - as in the research methodology: 1. Standard; 2. object (without biostimulators and herbicide); 3 . GreenOK Universal-PRO $0.10 \mathrm{dm}^{3} \mathrm{ha}^{-1}+0.15 \mathrm{dm}^{3} \mathrm{ha}^{-1}+0.15 \mathrm{dm}^{3} \mathrm{ha}^{-1}$; 4. Asahi SL $0.50 \mathrm{dm}^{3} \mathrm{ha}^{-1}+0.50 \mathrm{dm}^{3} \mathrm{ha}^{-1}$ $+0.50 \mathrm{dm}^{3} \mathrm{ha}^{-1}$; 5. Avatar $293 \mathrm{ZC} 1.5 \mathrm{dm}^{3} \mathrm{ha}^{-1}+$ GreenOK Universal-PRO $0.10 \mathrm{dm}^{3} \mathrm{ha}^{-1}+0.15 . \mathrm{dm}^{3} \mathrm{ha}^{-1}$ $+0.15 \mathrm{dm}^{3} \mathrm{ha}^{-1}$; 6. Avatar $293 \mathrm{ZC} 1.5 \mathrm{dm}^{3} \mathrm{ha}^{-1}$; n. s. - not significant difference

Whilst, in case of experimental objects 4 and 3 the largest weight and percentage share of large tubers (in fractions $>51 \mathrm{~mm}$ ) was noted. It amounted to, on average: 81.56 and $71.78 \%$ (Tab. 5). Such authors as Sawicka and Pszczółkowski (2003), Zarzecka et al (2014) indicate a positive impact of herbicides and their mixtures on the structure of potato crops. Matysiak and Adamczewski (2010), Trawczyński (2014) proved that foliar fertilization of potato plants using biostimulators has caused a decrease of the share of small tubers in general crop (in fractions up to $35 \mathrm{~mm}$ ) and an increase of the share of large tubers (in fractions: $50-60 \mathrm{~mm}$ and over $60 \mathrm{~mm}$ ). Kowalska (2016) noted a beneficial effect of microbiological substances on potato crop and its structure regardless of the substance used and the form of its application. 
Furthermore, Maciejewski et al. (2007) in their 2-year research concluded that using biostimulators Asahi SL and Atonik SL did not have any significant impact on the structure of potato tubers. Condor et al. (2006) shared a sceptical view on the topic of using microbiological preparations in plant production, stressing the need to conduct further scientific researches concerning their use.

Table 5. The impact of methods of treatment on the weight and percentage share of potato tubers in fractions $>51 \mathrm{~mm}$ (on average for cultivars and years 2015-2017)

\begin{tabular}{lccccccc}
\hline \multirow{2}{*}{ Methods* } & \multicolumn{5}{c}{ Cultivars } & \multicolumn{3}{c}{ Years } & Mean \\
\cline { 2 - 7 } & Bellarosa & Owacja & Vineta & 2015 & 2016 & 2017 & \\
\hline $1 *$ & 74.33 & 51.00 & 43.67 & 49.67 & 66.33 & 53.00 & 56.33 \\
3 & 79.00 & 58.33 & 50.67 & 51.67 & 72.33 & 64.00 & 62.67 \\
4 & 91.33 & 68.00 & 56.00 & 68.33 & 74.67 & 72.33 & 71.78 \\
5 & 93.00 & 80.67 & 71.00 & 75.00 & 86.00 & 83.67 & 81.56 \\
Mean & 86.00 & 65.67 & 53.00 & 59.67 & 72.00 & 73.00 & 68.22 \\
LSD (0.05) for: Years & 84.73 & 64.73 & 54.87 & 60.87 & 74.27 & 69.20 & 68.11 \\
& Cultivars & & & & & & 2.626 \\
& Methods & & & & & 2.626 \\
& Years $\times$ methods & & & & & 2.324 \\
& Cultivars $\times$ methods & & & & & n.s. \\
& & & & & & & n.s. \\
\hline
\end{tabular}

* - as in the research methodology: 1. Standard object (without biostimulators and herbicide); 2 . GreenOK Universal-PRO $0.10 \mathrm{dm}^{3} \mathrm{ha}^{-1}+0.15 \mathrm{dm}^{3} \mathrm{ha}^{-1}+0.15 \mathrm{dm}^{3} \mathrm{ha}^{-1}$; 3 . Asahi SL $0.50 \mathrm{dm}^{3} \mathrm{ha}^{-1}+0.50 \mathrm{dm}^{3} \mathrm{ha}^{-1}$ $+0.50 \mathrm{dm}^{3} \mathrm{ha}^{-1}$; 4. Avatar $293 \mathrm{ZC} 1.5 \mathrm{dm}^{3} \mathrm{ha}^{-1}+$ GreenOK Universal-PRO $0.10 \mathrm{dm}^{3} \mathrm{ha}^{-1}+0.15 . \mathrm{dm}^{3} \mathrm{ha}^{-1}$ $+0.15 \mathrm{dm}^{3} \mathrm{ha}^{-1} ; 5$. Avatar $293 \mathrm{ZC} 1.5 \mathrm{dm}^{3} \mathrm{ha}^{-1} ;$ n. s. - not significant difference

\section{The impact of genetic properties of different cultivars on the structure of potato tubers}

In the framework of own researches specific fractions of tubers were substantially modified by genetic features of the cultivated varieties of potato. When analysing the impact of varieties on the weight and percentage share of the fraction, it was concluded that Bellarosa variety had a decidedly larger share of tubers with a diameter of more than $51 \mathrm{~mm}$ (on average $84.73 \%$ ) than Owacja variety (on average $64.77 \%$ ) and Vineta (on average 54.87\%) (Tab. 5). Bellarosa variety also had the smallest percentage of small tubers (in fractions $<35 \mathrm{~mm}$ and $36-50 \mathrm{~mm}$ ) in general crop (Tabs 3 and 4). Turska et al. (2009) have also proven that the structure of potato crop is modified by the genetic characteristics of different varieties of potatoes. The authors emphasized that the use of yield possibilities of a given variety can be decided through the correct agricultural technology. Sawicka and Pszczółkowski (2017) have proved in their research that the interaction between genotype and environment have modified the structure of potato tubers to the largest extent. 


\section{The impact of thermal-precipitation conditions on the structure of potato tubers}

The structure of potato tubers has been shaped by weather conditions in the years of research. The most beneficial for the shaping of the structure of potato tubers in fractions over $51 \mathrm{~mm}$ was the growing season of 2016, in which the thermal-precipitation conditions were more favourable in comparison to the other years of research. Whilst, the biggest share of small tubers in the potato crop occurred in the post-drought and warm growing season in 2015 (Tabs 3 and 4). These results comply with the research carried out by Gugała et al. (2010), who concluded that the largest volume of small tubers (in fractions $<35 \mathrm{~mm}$ ) grew from potato plants in a warm and dry growing season, while the least appeared when the thermal-precipitation conditions were the most favourable. Lahlou et al. (2003) indicated that drought has a negative effect on the quality parameters of potato tubers. Kalbarczyk (1999), based on several years of research, noted that potato harvest can be affected negatively by insufficient, as well as excessive humidity of the soil. Zarzyńska (2010) in her research emphasized that a crucial element in potato cultivation is the right choice of potato variety, taking into consideration their environmental requirements.

\section{CONCLUSIONS}

1. The structure of edible potato tubers has been substantially influenced by the methods of treatment. Growth biostimulators and herbicides that were used in the experiment had a positive effect on the weight and percentage share of large tubers in general crop (in fractions $>51 \mathrm{~mm}$ ) as contrasted with the control experimental object that was treated solely in a mechanical way, in case of which a greater share of small tubers was observed.

2. The most effective manner of potato treatment in terms of the crop structure was using mechanical treatments until the emergence of plants and, right before the emergence, applying herbicide Avatar 293 ZC, and after the emergence, using bioactivator GreenOK Universal-PRO (experimental object 4), and until the emergence performing mechanical treatments, and after the emergence applying biostimulator Asahi SL (experimental object 3).

3. Genetic characteristics of the different varieties had an important impact on the structure of the crop - the greatest percentage share of large tubers in fractions over $51 \mathrm{~mm}$ was found in the Bellarosa cultivar; this variety had also the smallest share of small tubers. 
4. Weather conditions were noted to have an impact on the structure of potato tubers. The most beneficial, as compared with the other years of research, for the shaping of the structure of crop in fractions over $51 \mathrm{~mm}$ was the growing season of 2016, whereby total precipitation in the growing season amounted to $302 \mathrm{~mm}$ and the average ambient temperature equalled $14.9^{\circ} \mathrm{C}$.

Conflict of interest: The Author does not declare conflict of interest.

\section{REFERENCES}

Baranowska A., 2018. Impact of growth biostimulators and herbicide on edible potato yield. Acta Agroph., 25(4), 385-396, https://doi.org/10.31545/aagr/99211

Bulgari R., Cocetta G., Trivellini A., Vernieri P., Ferrante A., 2015. Biostimulants and crop responses: a review. Biological Agriculture \& Horticulture, 31(1), 1-17, https://doi.org/10.1080/01448765 .2014 .964649

Calvo, P., Nelson, L., Kloepper, J.W., 2014. Agricultural uses of plant biostimulants. Plant Soil, 383, 3-41, https://doi.org/10.1007/s11104-014-2131-8

Chotkowski J., Pilecki T., 2005. Attempt at elaboration of a synthetic method of evaluation of varieties of potato (in Polish). Bulletin IHAR, 237/238, 99-108.

Condor A.F., Perez P.G., Lokare Ch., 2006. Effective microorganisms: myth or reality. Revista Peruana de Biologia, 14(2), 315-319.

Du Jardin P., 2012. The Science of Plant Biostimulants - A bibliographic analysis. - Ad hoc Study Report to the European Commission DG ENTR.

Du Jardin P., 2015. Plant biostimulants: Definition, concept, main categories and regulation. -Scientia Horticulturae, 196, 3-14, https://doi.org/10.1016/j.scienta.2015.09.021

Essah S.Y.C., Delgado J.A., Dillon M., Sparks R., 2012. Cover crops can improve potato tuber yield and quality. Hort Technology, 22(2), 185-190, https://doi.org/10.21273/horttech.22.2.185

FAOSTAT 2019. Food and Agriculture Organization of the United Nations 2017. Statistical Pocketbook World Food and Agriculture. Retreived 27.12.2018 from https://www.potatopro. com/world/potato-statistics.

Gugała M., Zarzecka K., Mystkowska I., 2010. Presence of potato tuber defects under conditions of applying new generation insecticides. Biul. IHAR, 257/258, 103-109.

Jabłoński K., 2012. Modern potato production in the system of integrated agriculture. Agricultural Farming-Forestry Technique, 2, 1-4.

Jabłoński K., 2009. Directions of predicted changes in the potato production technology by 2020 . Studies and reports IUNG-BIP, 17, 117-127.

Kalbarczyk R., 1999. Impact of agro-meteorological factors on potato crops in Lubelskie voivodeship Scientific Journals of the Agricultural Academy in Szczecin 202, Agricultura 79, 91-98.

Kauffman G.L., Kneivel D.P., Watschke T.L., 2007. Effects of a biostimulant on the heat tolerance associated with photosynthetic capacity, membrane thermostability, and polyphenol production of perennial ryegrass. Crop Sci., 47, 261-267, https://doi.org/10.2135/cropsci2006.03.0171

Khan W., Rayirath U., Subramanian S., Jithesh. M., Rayorath P., Hodges M., Critchley A., Craigie J., Norrie J., Prithiviraj B., 2009. Seaweed Extracts as Biostimulants of Plant Growth and Development. Journal of Plant Growth Regulation, 28(4), 386-399, https://doi.org/10.1007/ s00344-009-9103-x 
Kowalska J., 2016. Effect of fertilization and microbiological bio-stimulators on healthiness and yield of organic potato (in Polish). Progress in Plant Protection/Postępy w Ochronie Roślin, 56(2), 230-235, https://doi.org/10.14199/ppp-2016-039

Krzysztofik B., Marks N., Baran D., 2009. The impact of selected agrotechnical factors on the quantitative characteristics of potato tuber crop (in Polish). Inżynieria Rolnicza, 5(114), 123-129.

Kunicki E., Grabowska A, Sekara A, Wojciechowska R., 2010. The effect of cultivar type, time of cultivation, and biostimulant treatment on the yield of spinach (Spinacia oleracea L.). Folia Hortic., 22, 9-13, https://doi.org/10.2478/fhort-2013-0153

Lahlou O., Ouattar S., Ledent J.F., 2003. The effect of drought and cultivar on growth parameters, yield and yield components of potato. Agronomie, 23(3), 257-268, https://doi.org/10.1051/ agro:2002089

Maciejewski T., Szukała J., Jarosz A., 2007. Impact of biostimulators Asahi SL and Atonik SL on quality characteristics of potato tubers. J. Res. App. Agric. Eng., 52(3), 109-112.

Matyjaszczyk E., 2015. Introduction of biostimulators into trade circulation in Poland. Current situation and legal conditions. Przemysł Chemiczny, 94(10), 1841-1844.

Matysiak K., Adamczewski K., 2010. Impact of growth and development of plant regulator Moddus 250 EC, Kelpak SL, Algaminoplant, Humiplant and Yield Plus on crop and size of potato tubers. Ziemniak Polski, 1, 28-33.

Nowacki W., 2005. Level of chemicalization in technology of potato crop in Poland. Prog. Plant Prot./ Post. Ochr. Roślin, 45(1), 317-324.

Potato market. Current state and perspectives 2000-2015. IERiGŻ-PIB. Warsaw.

Pszczółkowski P., Sawicka B., 2003. Productive capacity of very early potato varieties grown under covers. Part I. Crop and its structure. Acta Sc. Pol., 2(2), 61-72.

Radzka E., Rymuza K., 2015. Multi-trait analysis of agroclimate variations during the growing season in East-Central Poland (1971-2005). Int. Agrophys., 29, 213-219, https://doi.org/10.1515/ intag-2015-0021

Report by the Bank of Food Economy (Bank Gospodarki Zywnosciowej) - BGŻ BNP PARIBAS. 2015. Agro-conference. Warsaw.

Rymuza K., Radzka E., Lenartowicz T., 2015. The impact of environmental conditions on the content of starch in tubers of medium early potato cultivars (in Polish). Acta Agroph., 22(3), 279-289, https://doi.org/10.12911/22998993/59367

Sawicka B., Pszczółkowski P., 2017. Phenotypic changeability of crop and structure of very early and early potato varieties. Fragm. Agron., 34(1), 76-91.

Skowera B., 2014. Changes of hydrothermal conditions in the Polish area (1971-2010) (in Polish). Fragm. Agron., 31(2), 74-87.

Trawczyński C., 2014. Impact of amino acidic biostimulators - tecamin - on crop and quality of potatoes. Ziemniak Polski, 3, 29-34.

Turska E., Wielogórska G., Rymuza K., 2009. The influence of some agricultural factors on the quality of potato tubers. Fragm. Agron., 26(3), 156-161.

Vernieri P., Malorgio F., Tognoni F., 2002. Use of biostimulants in production of vegetable seedlings. Colture-Protette, 31(1), 75-79.

Zarzecka K., Grużewska A., Gugała M., Yatsyshyn A., 2017. Production and Quality of Table Potato in the Opinion of Consumers in Poland and Ukraine (in Polish). Zeszyty Naukowe Szkoły Głównej Gospodarstwa Wiejskiego w Warszawie. Problemy Rolnictwa Światowego, 17(3), 308318, https://doi.org/10.22630/prs.2018.18.4.106

Zarzecka K., Gugała M., Mystkowska I., Baranowska A., 2014. The effect of herbicides and their mixtures on the side yield of potato tubers (in Polish). Acta Agroph., 21(3), 375-385. 
Zarzyńska K., 2010. Structure of potato tuber crop grown in an ecological and integrated system in different environmental conditions. J. of Res. Applic. Agric. Eng., 55(4), 181-184.

Zarzyńska K., 2012. Impact of seed potatoes' sizes and density of planting on the number of sprouts and potato crop. Ziemniak Polski, 3, 1-4. 